\title{
De las orejas a la cola. Deleite, parodia y autoconocimiento en las representaciones simbólicas del asno y el mono en el Quijote (II, 24-28)
}

\author{
JULIA D’ONOFRIO*
}

\begin{abstract}
Resumen
Este trabajo busca atender a la representación cultural de dos animales que aparecen curiosamente unidos en el arco narrativo que va de los capítulos 24 al 28 del Quijote de 1615. En las construcciones simbólicas contemporáneas del asno y el mono se descubren implicancias ligadas a cuestiones como el deleite estético, la locura y el autoconocimiento que resuenan especialmente en los pasajes de los rebuznadores y del retablo de maese Pedro pero que se proyectan asimismo a toda la obra. El enfoque de análisis pretende recuperar motivos simbólicos y saberes comunes ligados a elementos presentes en la obra de Cervantes para procurar acercarnos a la constelación de alusiones que podían despertar tales menciones entre sus primeros lectores. Semejante recuperación puede iluminar redes de sentido que tal vez el tiempo y las transformaciones culturales han oscurecido para los lectores actuales.
\end{abstract}

Palabras clave: Cervantes; Quijote 1615; animales; cultura simbólica; deleite; autoconocimiento.

Title: From ears to tail. Delight, parody and self-knowledge in the symbolic representations of the ass and the monkey in Don Quijote (II, 24-28)

\begin{abstract}
This paper seeks to attend to the cultural representation of two animals that appear curiously coupled in the narrative arch that goes from chapter 24 to chapter 28 of the Second Part of Don Quixote. In symbolic constructions of the ass and the monkey, contemporary
\end{abstract}

* Universidad de Buenos Aires-CONICET, Instituto de Filología y Literaturas Hispánicas “Dr. Amado Alonso". juliadonofrio@gmail.com / ORCID iD: https://orcid.org/0000-0002-5512-5017. 
to Don Quixote, one discovers implications connected to issues like aesthetic delight, madness and self-knowledge that are evident especially in the passages about the braying aldermen and maese Pedro's puppet show but that may also project its light over the whole book. The analysis approach seeks to retrieve symbolic motives and common lores which are linked to elements present in the work of Cervantes, to achieve a view to the constellation of allusions that such references might awake in contemporary readers. This recovery may illuminate networks of meaning that perhaps time and cultural transformations have obscured for present day readers.

Keywords: Cervantes; Don Quijote part 2; Animals; Symbolic culture; Delight; SelfKnowledge.

\section{Cómo citar este artículo / Citation}

D’Onofrio, Julia (2018). «De las orejas a la cola. Deleite, parodia y autoconocimiento en las representaciones simbólicas del asno y el mono en el Quijote (II, 24-28)», Anales Cervantinos. 50, pp. 105-135, https://doi.org/10.3989/anacervantinos.2018.004.

\section{PLANTEO}

Encuadrado dentro de una investigación mayor sobre los diálogos de la obra de Cervantes con las ideas y prácticas simbólicas de su tiempo, este trabajo busca atender a la representación cultural de dos animales que aparecen curiosamente unidos en el Quijote de 1615, el asno y el mono.

Sabido es que el simbolismo que teñía la vida social y cultural del Siglo de Oro se fundaba en la idea de que Dios había cifrado mensajes trascendentes en toda su creación. Así pues, como una gran enciclopedia simbólica que podía dar cuenta de las correspondencias que entrelazaban la realidad visible y la inteligible, la naturaleza resultaba una fuente inagotable de ejemplos morales que los hombres de la época debían poder decodificar y aprovechar ${ }^{1}$. En este marco conceptual, los animales ocupan un lugar de especial importancia como modelos ejemplares para guiar el comportamiento del hombre y permitirle reflexionar sobre sus pasiones, pesares y modos de ser en el mundo. Al igual que las plantas y algunos seres inanimados, la mayoría de los animales conocidos en la Europa de los siglos XVI y XVII habían ido acumulando desde la antigüedad, y fortaleciendo durante la Edad Media, un gran

1. Como dice el elocuente párrafo de R. de la Flor: «Antes de que la ciencia moderna de un Hume asiente las nociones de caos, de azar de explosión originaria (y, en definitiva, de 'ilegibilidad' del mundo en términos morales y mucho más en los políticos) y, sobre todo, antes de que la naturaleza se deje leer exclusivamente bajo los parámetros matemáticos que utiliza la ciencia moderna, esa misma naturaleza entera es representada al modo de un ordenado documento textual, lección de política, incluso antes de que la política y la historia existieran, y por lo tanto volumen creaturarum, susceptible de ser interrogado en una práctica de la exégesis, y de encontrarse en él con que, como escribe el editor de Plinio a finales del siglo XVI, Jerónimo de la Huerta, los elementos de la naturaleza: 'Letras son que con mudas lenguas nos exortan a lo que devemos guardar, y con parlero silencio nos amonestan lo que devemos seguir'» (R. de la Flor 1999: 80). 
número de asociaciones simbólicas de acuerdo a las cualidades y rasgos que se ponían de relieve en cada caso $^{2}$.

El análisis que planteo pretende reflexionar acerca de las resonancias que semejante cúmulo de saberes e ideas compartidas puede tener en un texto literario que no se presenta como simbólico, ni mucho menos convoca a una lectura alegórica unívoca. Mi enfoque propone recuperar motivos simbólicos y saberes comunes ligados a elementos presentes en la obra de Cervantes para procurar acercarnos a la constelación de alusiones que podían despertar tales menciones entre sus lectores contemporáneos. Bucear en ese tipo de alusiones simbólicas, además, nos permite descubrir líneas interesantes para profundizar ideas claramente puestas de manifiesto en el relato y completar posibles interpretaciones sin alejarnos de la lectura literal del texto sino, por el contrario, apoyándonos en otros contenidos que su materialidad nos ofrece.

\section{ARS SIMIA NATURAE}

La imbricación de los episodios de los rebuznadores y de maese Pedro con el mono adivino ha llamado la atención de la crítica en numerosas ocasiones. El entrelazamiento es notable y, sin duda, la cuestión de la imitación — tan central en las reflexiones artísticas del Renacimiento - tiene aquí una continuidad significativa de importancia capital (los regidores que imitan al asno, el mono que imita el habla del hombre y la más compleja cuestión de la mímesis en la representación artística del espectáculo de títeres).

Sin embargo, quisiera poner el foco ahora en las implicancias que tienen las figuras simbólicas del mono y del asno en estos capítulos, puesto que las ideas ligadas a sus particulares representaciones culturales sobrevuelan el arco narrativo que va desde el capítulo 24 al 28 y también contribuyen a profundizar ciertas temáticas que recorren la obra ${ }^{3}$.

Apenas empezamos a bucear en la representación cultural del mono no nos quedan dudas de que el rasgo más frecuente que se extiende por todas las diversas tradiciones culturales es el de la imitación ${ }^{4}$; podríamos decir que es

2. Se trata, por supuesto, de un bagaje vivo y multiforme que refleja tanto rasgos invariantes y acumulaciones, como también notables modificaciones según las épocas. García Arranz que mucho ha estudiado la animalística en la cultura simbólica del período (véase por ejemplo su monumental volumen sobre las aves, 2010), ajusta en un reciente trabajo la vinculación del Physiologus con la emblemática (2014).

3. Alberto Rodríguez (2004) también analizó significados simbólicos ligados a estos animales y en especial al asno, pero creemos que cabe prestar más atención a las múltiples valencias del simbolismo que tenían en la época de Cervantes.

4. Las muy ricas tradiciones culturales con respecto a los monos tienen un estudio fundamental en el libro de H. W. Janson, Apes and Ape Lore in the Middle Ages and the Renaissance, surgido del Instituto Warburg y publicado en 1952. El libro de Janson hace un recorrido a través la representación cultural de los monos desde la Alta Edad Media, registra las notables transformaciones que se producen en la Baja Edad Media y termina por atender su representación en las distintas fases del Renacimiento que llegan hasta el Barroco. 
prácticamente el rasgo invariable que recorre siglos de tradiciones y representaciones diferentes. Son innumerables las conceptualizaciones que se han hecho sobre la acción mimética de los monos, con miradas positivas o negativas según cómo se considere la calidad de su imitación. A lo largo de los siglos, por lo general, los monos han sido más que nada el modelo de las imitaciones defectuosas o toscas; sin embargo, en los albores del Renacimiento se descubre un cambio de mirada que puede apreciarse al notar el gran relieve que alcanza la sentencia ars simia naturae, «el arte es la simia de la naturaleza» ${ }^{5}$.

La visión invariablemente negativa en la Antigüedad con respecto a cualquier acción de los monos incluía la imitación simiesca considerada epítome de lo torpe, deforme o mal hecho; tal visión recorre también el pensamiento medieval como la imagen de la mala copia, del mal actor o de la farsa. Así pues, en línea con las disquisiciones platónicas sobre la representación artística, Alain de Lille a fines del siglo XII había difundido el concepto ars simia veri, el arte - especialmente la pintura y la escultura - es la mona de la verdad porque no hace más que falsificar la realidad. Frente a este panorama, Janson señala una transformación sustancial que introduce Boccaccio cuando sostiene que el poeta es simia naturae porque imita con sus versos la totalidad de la naturaleza. La diferencia entre simia de la verdad y simia de la naturaleza es muy destacable, pero lo más distintivo de esta caracterización del arte es que considera la labor imitativa como positiva y honrosa ${ }^{6}$. La amplia reflexión que suscita la imitación en el arte del Renacimiento postula la cuestión no solo ya como copia de la naturaleza, sino también y especialmente en términos del ejemplo que se obtiene de otros artistas o poetas; es decir, la consabida imitación de modelos ${ }^{7}$. El concepto de ars simia naturae permaneció vigente en el Renacimiento con sentido positivo hasta finales del siglo XVI, cuando empieza a cuestionarse el peso de la imitación como actividad central del artista.

5. Janson hace un esclarecedor recorrido sobre este concepto (1952: 287-325).

6. Es en el libro XIV de su De Genealogia Deorum, dedicado a la defensa de la poesía. Incluso la exaltación del valor de la imitación lo lleva a afirmar que de la misma manera que un artista imita la naturaleza, un buen cristiano debería buscar ser un buen simio de Cristo. Al respecto dice Janson: «The analogy between the artist as the ape of nature, and the good Christian as the ape of the Saviour, demonstrates the extent to which Boccaccio had departed from the mediaeval meaning of simia; to him it no longer suggested an inept and ignoble imitator [...] but one who strives to come as close as possible to a great ideal, be it aesthetic or moral. [...] Thus the author of the Geanealogia must be regarded as the originator of the Renaissance concept of ars simia naturae, as against the mediaeval simia veri with its invidious distinction between reality and representational art, the 'forgery of realilty'» (Janson: 293).

7. Deben ser recordadas las clásicas páginas de Riley sobre la imitación artística que realiza don Quijote en Sierra Morena. El cervantista inglés abordó este tema en varias oportunidades; pero en su formulación más completa (Riley 1954) hallamos bien desarrolladas las discusiones renacentistas sobre los diversos modos de imitación a partir de las reflexiones de Petrarca, así como la influencia de tales teorizaciones en la literatura contemporánea a Cervantes. 
De manera especial, cuando se reflexionaba sobre la imitación de modelos era un tópico común menospreciar al mal artista como aquel que solamente copia sin gracia lo ya hecho por otros creadores.

Así pues, se llega a representar la imitación del mono como imitatio insipiens, la imitación del necio, que copia indiscriminadamente, en contraposición a la imitación sabiamente realizada, propia del verdadero $\operatorname{artista}^{8}$. En efecto, la figura del mono suele utilizarse como epítome de la imitación servil, la que queda atada a un único modelo que se copia sin criterio, y se diferencia de la imitación compuesta que elige lo mejor de diferentes modelos y hace oír la voz individual del creador ${ }^{9}$.

En el inmediato contexto cultural de Cervantes, tales representaciones tienen plena vigencia, como nos lo muestra el testimonio del Tesoro de la lengua castellana (1611) de Covarrubias donde la idea de la imitación es una de las más repetidas en las entradas sobre monas, simias y micos ${ }^{10}$; o, también, en la Iconología de Ripa (1593) de enorme difusión europea ${ }^{11}$. Por lo demás, podemos encontrar autores muy cercanos a Cervantes que, como ya habían hecho los humanistas, representan con la figura del mono el ejemplo de la mala imitación artística; tal es el caso de Luis Alfonso de Carballo con su

8. De manera que se vuelve a despreciar la figura del mono como imagen general del buen artista (Janson 1952: 303-304).

9. Cuestiones que bien sabemos recorrieron las discusiones literarias desde los inicios del Renacimiento. Petrarca por ejemplo en una de sus epístolas sostenía que un buen poeta debe imitar el espíritu de sus modelos, no sus palabras precisas, porque ese modo de actuar hace monos, no poetas (Familiares, XXIII.19). En desarrollos posteriores de la polémica sobre la imitación, tal equiparación con los monos se mantiene constante, en oposición a la famosa metáfora, rescatada por Petrarca de Séneca y Horacio, acerca de la buena imitación como la labor de las abejas que liban de flor en flor para producir la miel. Durante el siglo XVI toda la discusión se reavivó en torno a la figura de Cicerón y a sus imitadores más extremistas. El Ciceroniano de Erasmo, publicado en 1528, mantuvo muy viva la polémica. Véase una interesante puesta al día en Mañas Núñez (2009) con numerosas citas que reflejan el uso del mono como metáfora del imitador torpe.

10. La mayoría de los ejemplos, fábulas o núcleos narrativos que tratan de monos refieren a hembras, así es mucho más común en las figuras del mono como metáfora (para copiar a Curtius y su Excursus XIX) que se hable de animales hembras, tal vez como una manera misógina de destacar la semejanza con el hombre, pero también su imperfección.

11. En la obra de Ripa la mona aparece como figura de la imitación en dos alegorías distintas; una en la que se representa a la Imitación misma del arte donde una mona es símbolo de la imitación de las acciones humanas; y otra en la que se habla de la Comedia Vieja y las imitaciones toscas o grotescas de las costumbres: «Mujer vieja y risueña, aunque con rostro agrio y expresión poco agradable. (...) Ante ella se pondrá una mona, que le ofrece una cestilla cerrada, abriéndola la mujer con su mano izquierda; de este modo se han de ver diversos, horribles y venenosos animales, víboras, áspides, sapos y otros bichos semejantes. (...) Así, siendo el objeto de la Comedia Vieja el resaltar los vicios de los hombres, provocando la risa a cuenta de sus acciones y necedades, la hemos querido representar con tal aspecto y actitud que por sí sola se la reconozca. (...) La mona que le ofrece una cestilla simboliza la grosera imitación, mediante la cual resaltaba los vicios y necedades de los hombres; siendo éstos los sucios y venenosos animales que muestra al pueblo la mujer, utilizando para ello la risa y el escarnio» (Ripa: «Comedia Vieja»). Por lo demás, la idea del mono como imagen misma de la farsa se sostiene en una tradición de peso en la cual la imitación histriónica del mono se convertía en parodia. Sobre la imitación histriónica del mono y las apariciones de monos sobre los escenarios, ya sea reales o representados por actores, para cuadros grotescos, ver Knowles, 2004. 
Cisne de Apolo (1602) ${ }^{12}$. En esta obra, hacia el final del diálogo IV, el personaje de la Lectura sostiene que se debe imitar a los poetas más acreditados y de ellos lo mejor que tuvieren; para explicarlo, usa la mona como ejemplo vitando: "Ansi que lo bueno de otro poeta es lo que ha de seguir el imitador, y no hacer como la mona, que queriendo imitar y parecer al hombre, no le imita ni parece en lo mejor, que es el sentido, sino en la liviandad de la risa y en las nalgas» (Carballo 1958: 182).

De esta mirada burlesca sobre el tópico surgen las imágenes de monos pintores con la idea implícita del «artista como un mono» en tono despreciativo: risueñas parodias sobre los pintores, sus torpezas y sus vanidades. Veremos llegar esta postura hasta el mismo Goya y sus Caprichos, de fines del siglo XVIII, como en el número 41 «Ni más ni menos» donde reúne al mono y al asno: el mono como pintor torpe y el asno como el único que puede llegar a juzgarlo como un verdadero artista y por eso se deja retratar por él. O el número 38 «Bravísimo!» en el que un mono toca la guitarra (al revés) y el asno es espectador y juez. Luego volveremos sobre esta distribución de papeles.

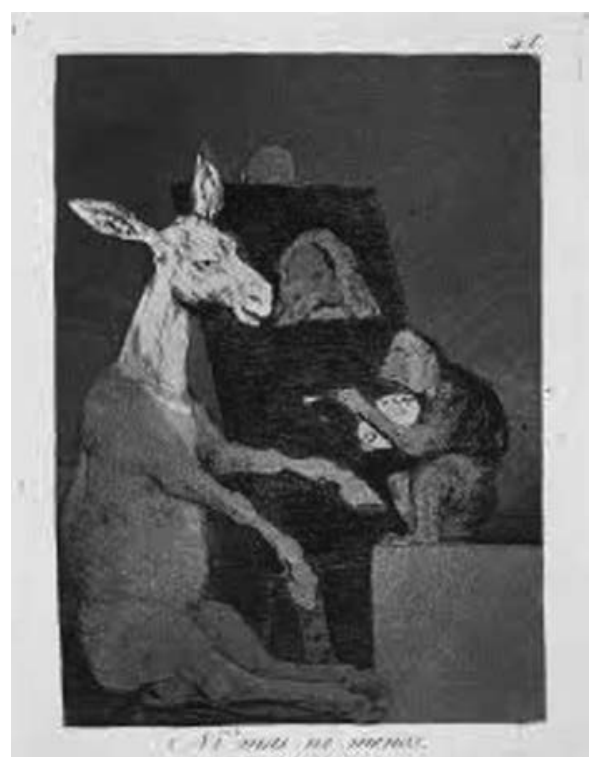

FigurA 1. Francisco Goya y Lucientes Capricho 41.

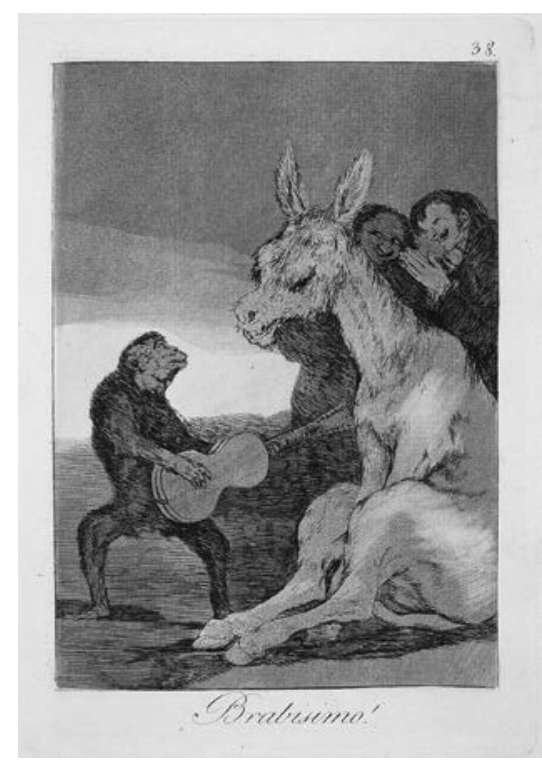

FIGURA 2. Francisco Goya y Lucientes - Capricho 38.

En los capítulos del Quijote que analizamos, la figura del mono adivino refleja una realidad común y verosímil del animal como atracción en espec-

12. La tesis de doctorado de Noelia Vitali, defendida en octubre de 2016 en la Universidad de Buenos Aires, propone interesantes relaciones entre este tratadista y Cervantes. 
táculos itinerantes. Es claro también que, de entre los múltiples rasgos de la representación cultural del mono ${ }^{13}$, en este episodio lo más central es la cuestión del arte y de la mímesis, como de modo elocuente ha sido señalado por la crítica (Haley, Percas de Ponseti, Gaylord, Parodi, Collins). El acto mismo del mono adivino se fundaba en la imitación histriónica: el mono actúa como un hombre que habla y maese Pedro finge que aquello que le dice al oído lo adivinaba de sus espectadores.

Es innegable también que el tema de la imitación artística es central en todo el episodio de maese Pedro por los conflictos que despierta la puesta en escena de la historia de Gaiferos y Melisendra en el retablo de títeres ${ }^{14}$; pero, curiosamente, los conflictos de esta representación en el retablo —imitación verosímil o fallida farsa caballeresca- de ninguna manera involucran al mono, salvo por el hecho de que huye después del ataque de don Quijote. Sin embargo, precisamente por esta disociación podemos descubrir la importancia conceptual y figural de la imitación en estos capítulos, ya que vemos tratar el asunto en diversos niveles y sentidos del texto. Por un lado, hallamos la cuestión de cómo se pone en escena la historia $\mathrm{y}$, por otro, la curiosa presencia del mono se nos aparece como índice simbólico de la cuestión. Me atrevo a señalar, entonces, que parece bastante inmotivada la presencia del mono en el episodio del retablo, salvo por su preponderante función emblemática: aunque el mono es poco necesario para la acción, se yergue en toda la escena como el indicador referencial del concepto de la imitación.

Todas estas relaciones cobran una dimensión más evidente aún si prestamos atención a la aventura de los rebuznadores que enmarca el episodio del retablo de maese Pedro. Haley (1965) ya había indicado la sutileza cervantina de combinar la figura de un animal que imita al hombre con la de unos hombres que imitan el rebuzno de los asnos. Alicia Parodi (2006) también señaló las peculiaridades de la unión de las dos escenas ${ }^{15}$. Por mi parte, quisiera acentuar estas conexiones y hacer ver que en ellos se pone en primer plano a dos animales modélicos de enorme carga simbólica como figuras ejemplares de la condición humana, pero también en lo que toca a sus respectivas relaciones con la creación y la valoración artística.

Esto último me interesa sobremanera; creo que es importante destacar que en ambos episodios, además de la imitación, se dramatiza especialmente la idea del entretenimiento y el disfrute artístico. De hecho, tiene en todo momento un papel destacado la figura de don Quijote como receptor y se repite su peculiar entusiasmo como consumidor de diversos tipos de espectáculos. Suele recordarse siempre su figura de espectador frente al acto de maese Pedro, pero tampoco se debe olvidar que el relato de los dos regidores que

13. Lujuria, vanidad, engaño, etc. ( $c f$. Janson y un recorrido de otros lazos cervantinos en D’Onofrio 2016).

14. Las lecturas de Haley y Gaylord siguen siendo ineludibles.

15. Amplió sus lecturas en Parodi 2017: 136 y ss. 
rebuznan crea muchas expectativas en el caballero, sus acompañantes y, por supuesto, en nosotros, los lectores.

\section{LA MARAVILLA DEL REBUZNO Y EL ASNO JUEZ}

Como un relato de grandes maravillas anuncia su historia el portador de las lanzas con quien se cruzan el capítulo 24 y de manera notable incita la curiosidad de don Quijote. Veamos cómo se presenta en el texto:

Estando en esto, vieron que hacia donde ellos estaban venía un hombre a pie, caminando apriesa y dando varazos a un macho que venía cargado de lanzas y de alabardas. Cuando llegó a ellos, los saludó y pasó de largo. Don Quijote le dijo:

-Buen hombre, deteneos, que parece que vais con más diligencia que ese macho ha menester.

- No me puedo detener, señor — respondió el hombre-, porque las armas que veis que aquí llevo han de servir mañana, y, así, me es forzoso el no detenerme, y a Dios. Pero si quisiéredes saber para qué las llevo, en la venta que está más arriba de la ermita pienso alojar esta noche; y si es que hacéis este mesmo camino, allí me hallaréis, donde os contaré maravillas. Y a Dios otra vez.

Y de tal manera aguijó el macho, que no tuvo lugar don Quijote de preguntarle qué maravillas eran las que pensaba decirles, y como él era algo curioso y siempre le fatigaban deseos de saber cosas nuevas, ordenó que al momento se partiesen y fuesen a pasar la noche en la venta, sin tocar en la ermita, donde quisiera el primo que se quedaran (II, 24. Aquí y en las siguientes citas las itálicas son mías).

Apenas llegados a la venta, don Quijote se muestra tan ansioso por conocer ese maravilloso suceso que se «rebaja» a hacer tareas de caballerizo para que el portador de las lanzas (y del relato) pueda empezar su cuento lo antes posible:

No se le cocía el pan a don Quijote, como suele decirse, hasta oír y saber las maravillas prometidas del hombre condutor de las armas. Fuele a buscar donde el ventero le había dicho que estaba, y hallóle y díjole que en todo caso le dijese luego lo que le había de decir después acerca de lo que le había preguntado en el camino. El hombre le respondió:

-Más despacio, y no en pie, se ha de tomar el cuento de mis maravillas: déjeme vuestra merced, señor bueno, acabar de dar recado a mi bestia, que yo le diré cosas que le admiren.

-No quede por eso - respondió don Quijote—, que yo os ayudaré a todo. $\mathrm{Y}$ así lo hizo, ahechándole la cebada y limpiando el pesebre, humildad que obligó al hombre a contarle con buena voluntad lo que le pedía; y sentándose en un poyo, y don Quijote junto a él, teniendo por senado y auditorio al primo, al paje, a Sancho Panza y al ventero, comenzó a decir desta manera... (II, 25). 
Frente al repetido anuncio de la maravilla y el gran interés que despierta el portador, luego nos encontramos, sin embargo, con que la historia de los dos regidores no tiene nada de maravillosa. Puede ser que sea divertida, curiosa, notable, pero no maravillosa. Lo cierto es que los únicos admirados y quienes hablan de maravillas son los protagonistas del cuento. Pero ¿en qué medida, entonces, se traslada el asombro a los oyentes directos del relato y a nosotros lectores?

Adecuadamente, como si se buscara adrede dejar planteado el tema sin resolverlo, al terminar el relato del hombre de las lanzas, el texto no deja espacio para sopesar la reacción de sus receptores directos, pues intempestivamente se anuncia la llegada de Maese Pedro, con su mono y su retablo de títeres y el entusiasmo del ventero al recibirlo promete un admirable espectáculo, dejando lo anterior en el olvido ${ }^{16}$.

Estas incongruencias y estas ausencias vuelven más imperiosa la pregunta que se nos plantea, acerca de dónde está lo maravilloso del cuento de los rebuznadores. Más allá de reconocer lo risueño de presentar un relato que promete mucho y ofrece poco, y que, por lo tanto, permite una mirada paródica de la figura del rústico contador de cuentos, creo que es necesario destacar los espacios del relato que representan la maravilla en términos del disfrute estético que experimentaron sus protagonistas ante el «arte» del rebuzno. Efectivamente, hay una isotopía ligada al arte y la creación que recorre la historia de manera tan absurda que no debemos dejar de verla.

Notemos que ya desde el principio, la idea para la búsqueda a puros rebuznos es presentada por los regidores como un despliegue creativo de ingenio que procura servirse de sus «maravillosas habilidades»:

«Mirad, compadre: una traza me ha venido al pensamiento, con la cual sin duda alguna podremos descubrir este animal, aunque esté metido en las entrañas de la tierra, no que del monte, y es que yo sé rebuznar maravillosamente, y si vos sabéis algún tanto, dad el hecho por concluido». «¿Algún tanto decís, compadre? - dijo el otro-. Por Dios, que no dé la ventaja a nadie, ni aun a los mesmos asnos» (II, 2).

Notemos además que, en un gracioso cruce entre rusticidad y tradición culta, el primero tiene la confianza de contar con el poder de Orfeo, el epítome del poeta que con su canto podía rescatar a los muertos y sacarlos precisamente «de las entrañas de la tierra».

Así pues, planean el desarrollo de la traza y pronto empiezan a rebuznar por el monte de manera tan verosímil que ellos mismos se confunden por la «ilusión mimética» (al decir de Haley) de su artificio:

16. La narración no deja resquicio alguno entre un relato y otro: «Y con esto dio fin a su plática el buen hombre, y en esto entró por la puerta de la venta un hombre todo vestido de camuza, medias, greguescos y jubón, y con voz levantada dijo: - Señor huésped, ¿hay posada? Que viene aquí el mono adivino y el retablo de la libertad de Melisendra. — ¡Cuerpo de tal — dijo el ventero—, que aquí está el señor mase Pedro! Buena noche se nos apareja» (II, 25). 
«¿Es posible, compadre, que no fue mi asno el que rebuznó?». «No fue sino yo», respondió el otro. "Ahora digo - dijo el dueño- que de vos a un asno, compadre, no hay alguna diferencia, en cuanto toca al rebuznar, porque en mi vida he visto ni oído cosa más propia» (II, 25).

Como vemos, el «arte» de ambos es como el arte tosco del mono, que puede copiar miméticamente, pero nada más que esto y para sumar al tono de farsa, ahí está el peculiar halago que se hace de ser igual a un asno. Pero además es necesario notar que ambos intercambian absurdas alabanzas que remedan el lenguaje preciso de los juicios poéticos y hasta la apreciación musical:

«Esas alabanzas y encarecimiento — respondió el de la traza- mejor os atañen y tocan a vos que a mí, compadre, que por el Dios que me crió que podéis dar dos rebuznos de ventaja al mayor y más perito rebuznador del mundo: porque el sonido que tenéis es alto; lo sostenido de la voz, a su tiempo y compás; los dejos, muchos y apresurados; y, en resolución, yo me doy por vencido y os rindo la palma y doy la bandera desta rara habilidad». «Ahora digo — respondió el dueño- que me tendré y estimaré en más de aquí adelante, y pensaré que sé alguna cosa, pues tengo alguna gracia, que puesto que pensara que rebuznaba bien, nunca entendí que llegaba al estremo que decís». «También diré yo ahora — respondió el segundo-que hay raras habilidades perdidas en el mundo y que son mal empleadas en aquellos que no saben aprovecharse dellas». «Las nuestras — respondió el dueño-, si no es en casos semejantes como el que traemos entre manos, no nos pueden servir en otros, y aun en este plega a Dios que nos sean de provecho» (II, 25).

Cabe recordar aquí algunas representaciones culturales vigentes en la época sobre los asnos, porque pareciera que el texto juega parte de su comicidad en el entendimiento de esas alusiones. Más allá de una mirada positiva que destacaba en el asno la humildad y la resistencia al trabajo, los significados predominantes en torno a este animal se volcaban, como en nuestros tiempos, hacia las ideas de necedad, tosquedad e ignorancia ${ }^{17}$. Con todo, como ya vimos en los ejemplos de Goya, en estas visiones negativas del animal se apuntaba especialmente a denunciar sus malos juicios y a constituir al asno como figura arquetípica del mal juez especialmente en cuestiones musicales $\mathrm{o}$ artísticas.

En efecto, el asno como figura del juez torpe aparece como una simbolización común en obras contemporáneas al Quijote, así podemos ver el emblema de Juan de Horozco (Emblemas morales, cuya primera edición es de

17. El asno tiene un completo estudio en el trabajo de M. Guillemont y Marie-Blanche Requejo Carrió (2007). Las autoras analizan la cuestión asinina como punto de comparación entre Mateo Alemán y Cervantes, de modo que se trata no solo de una investigación ligada a la época sino también específicamente a la obra de Cervantes. Por supuesto, de especial interés son también los trabajos clásicos de Monique Joly (1983 y 1986). 
1589) que representa al asno sentado en un estrado, juzgando la disputa entre el ruiseñor y el cuclillo. El mote en castellano es claro: «Qual juez tal sentencia» y el emblema busca advertir sobre el peligro de los jueces ineptos e ignorantes ${ }^{18}$.

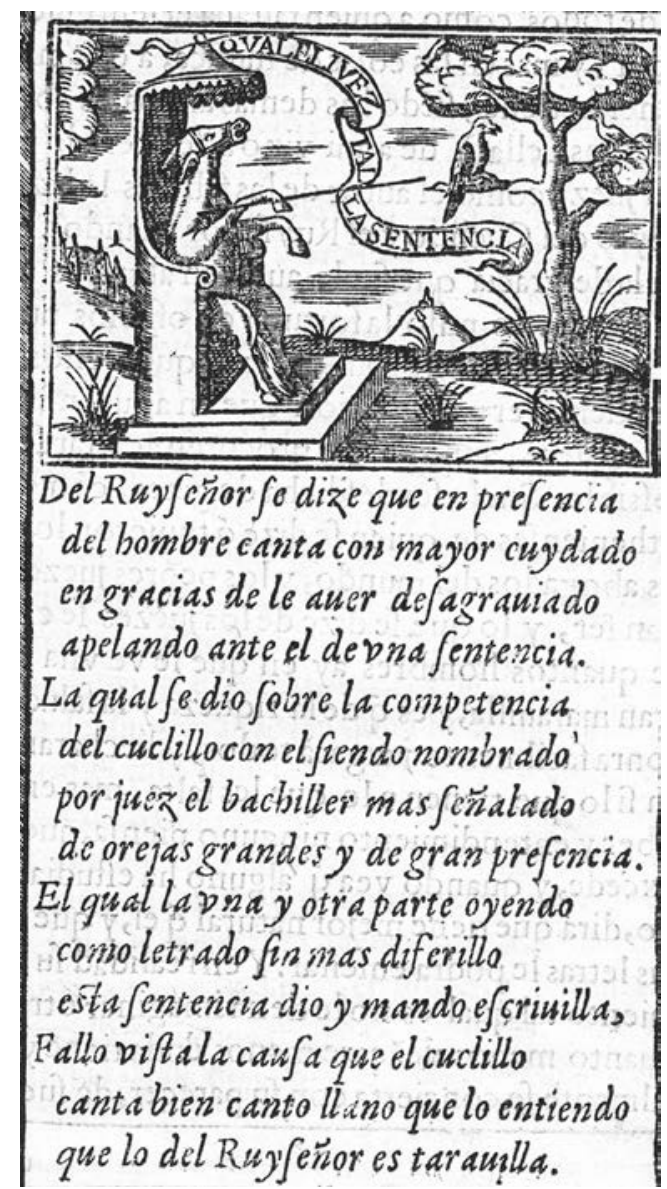

Figura 3. Horozco, Emblemas morales, Centuria III, emblema 10.

18. Se ve en el poema epigramático que el asno se decanta por el canto llano del cuclillo frente al más refinado del ruiseñor que no logra entender: «Fallo vista la causa que el cuclillo / canta bien canto llano que lo entiendo / que lo del Ruyseñor es taravilla». En el principio de la glosa, Horozco apunta: «El animal humilde y nacido para el trabajo con tener las orejas grandes, y ser de gran oydo por la torpedad que en sí tiene fue siempre tenido en poco, y despreciado de todos como a quien faltava el sentimiento el oyr, y en las cosas de música, a que ninguna atención tiene, siendo los demás animales como inclinados a ella. Y de aquí vino a ser tenido por tan mal juez, como el autor de las fábulas le hizo en el pleyto del Cuclillo y el Ruyseñor [...]» (Libro III, emblema 10, f. 120 v). 
Alonso de Carballo en su Cisne de Apolo (1602) otra vez nos sirve de comparación, porque retoma la misma fábula con propósitos argumentativos semejantes a los de Horozco ${ }^{19}$ y suma, además, otro lugar común famoso: la referencia a las orejas de burro del rey $\operatorname{Midas}^{20}$. En el diálogo, para señalar que uno de los interlocutores había hecho un comentario improcedente, el personaje de la Lectura lo reprende diciendo: «O tú no oíste lo que tratábamos, o tienes orejas de asno, como se dice que tenía Midas, porque juzgó por mejor la música de un pastor que la de Apolo». La fábula de cómo se había ganado el Rey Midas sus orejas de asno fue también muy socorrida en la época y, como se ve, repite asimismo la cuestión del juicio insensato ${ }^{21}$. En la emblemática española aparece más de una vez; por ejemplo en este emblema de Villava donde representa la idea del mal juicio del vulgo; el mote reza: Judicio fors digna meo [el resultado es digno de mi juicio] (Fig. 4).

Comprobamos, pues, que el asno estaba asociado directamente al juicio torpe $^{22}$. Bien sabido es que el mal juicio o la apreciación equivocada (y lo digo a conciencia, haciendo hincapié en el hecho de que se considera que existe una elección correcta y otra incorrecta) eran la marca más definitoria del ser necio, tonto o loco; y el asno lleva todas las de perder como animal modélico de esta conexión, como en seguida veremos.

Si regresamos a los regidores del Quijote con estas referencias sobre el asno y los juicios, podemos notar que resultan doblemente satíricas las mutuas alabanzas a la maravillosa habilidad de la que hacen gala los rebuznadores, por un lado por el hecho mismo de tratarse de un arte de rebuznos y por otro porque con sus juicios insensatos confirman ser unos asnos (asnos son por rebuznar como tales y asnos son por juzgar como acción maravillosa, casi artística, lo que no lo merece).

19. El personaje de Carvallo interviene inmediatamente para acotar: «Carva. - Cuando yo era niño me solían entretener con un cuento que viene a propósito, y es, que el ruiseñor y el cuclillo tuvieron gran diferencia sobre cuál cantaba mejor, y compromisaron el negocio en manos del señor asno, dándole poder bastante para sentenciar la causa. El cual, oídas las partes, sentado en su tribunal pronuncia por su sentencia que el cuclillo cantaba mucho mejor, por cantar en canto llano que él entendía, y que el ruiseñor no hacía más que una tarabilla» (Diálogo primero, parágrafo 3, p. 53). Un emblema de la colección de Andrés Mendo, Príncipe perfecto de 1642, muestra la pervivencia de la misma idea: apunta contra la mala elección de jueces ineptos con la imagen de un asno sentado en un estrado de juez (véase Bernat Vistarini et al. 1999, emblema n. ${ }^{\circ} 183$ ).

20. La frase «Midas aurículas asina» era proverbial y por supuesto aparece incluida en los Adagia de Erasmo y comentado por Covarrubias en su Tesoro al hablar de los asnos.

21. Entre los autores clásicos, se cuenta en las Metamorfosis XI, vv. 483-485 y en la Sátira primera de Persio. El rey Molo juzgó a favor de Apolo en una competencia entre él y Pan sobre cuál era mejor músico. Midas estaba presente y se quejó del juicio porque él prefería la rústica música de Pan antes que la de Apolo. En castigo por esto, Apolo le hizo crecer orejas de burro como símbolo de su juicio insensato.

22. Eso mismo indica también el refrán repetido en las obras de Cervantes: «No es la miel para la boca del asno» que se liga a la cuestión de la elección torpe, la de aquel que no sabe apreciar lo que es bueno. En D’Onofrio 2018, capítulo 5, se encuentra un rastreo de ciertas conexiones en la representación cultural de la lectura de este refrán en La ilustre fregona. 


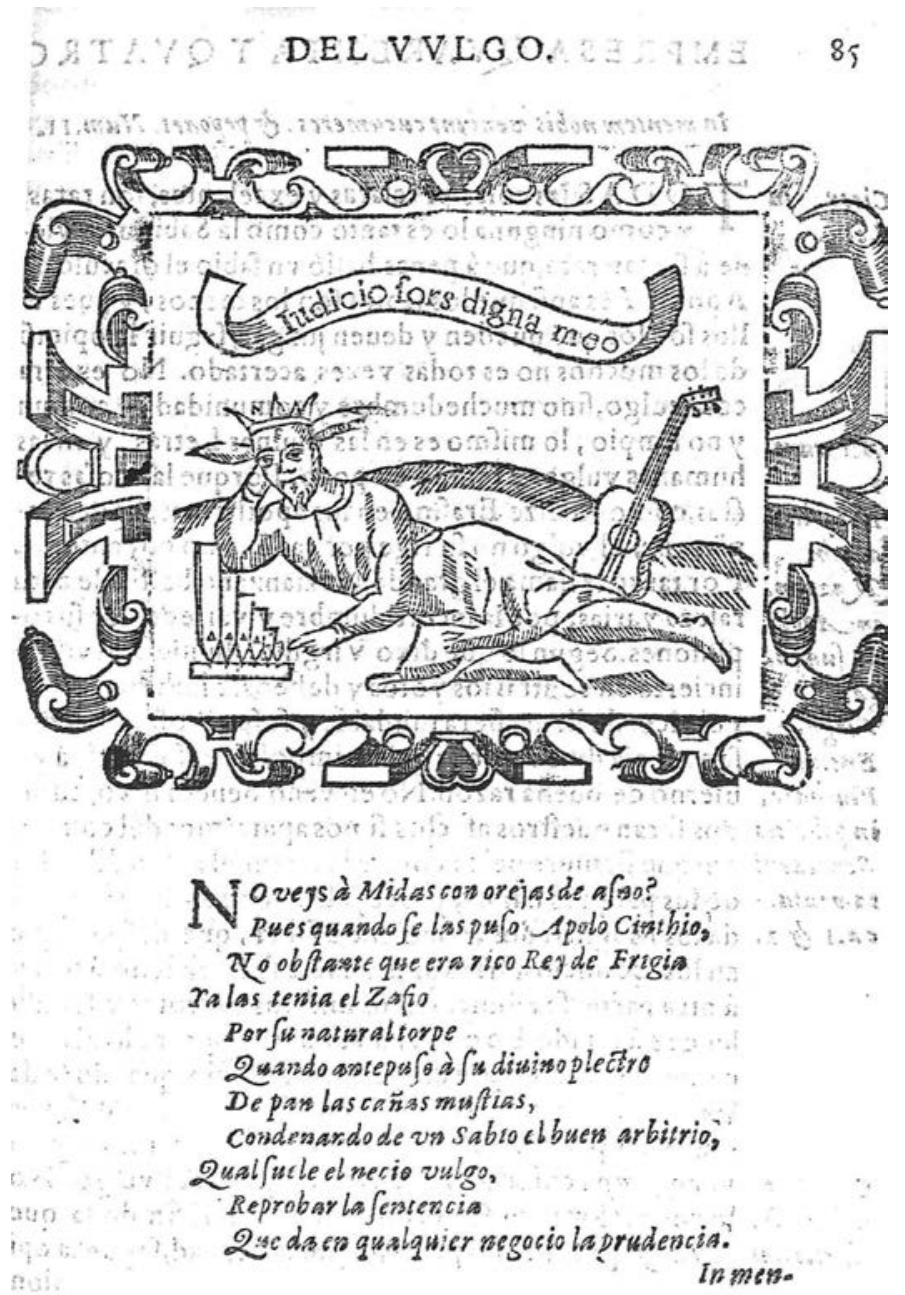

Figura 4. Villava, Empresas espirituales y morales, Segunda parte, 44, f. 85r.

Bien sabemos que la crítica ha leído este curioso episodio como una burla al torpe continuador escondido bajo el nombre de Avellaneda ${ }^{23}$; desde ya que el ridículo de los rebuznadores no puede dejar de advertirse, pero como suele suceder en las obras cervantinas parece haber también una ambigüedad en la burla que permite invertir la mirada negativa o al menos sumarle otra perspectiva. En este relato pareciera que queda un resquicio de redención en el hecho de que no deja de despertar cierta simpatía el consuelo que los dos regidores se dan ante lo fallido de su empresa cuando encuentran muerto al asno que buscaban.

23. Al respecto, véase el reciente y completo trabajo de Ly (2016). 
A la vez retomando, pero también desafiando los postulados del mal juicio y la mirada admonitoria, que la tradición cultural recién reseñada postula sobre qué es lo adecuado y qué es lo equivocado en los juicios artísticos, nos encontramos con que los rebuznadores, quienes ya se habían preguntado por el provecho de su «rara habilidad», se consuelan destacando el deleite que ambos experimentaron al oír rebuznar al otro.

«Ya me maravillaba yo de que él no respondía, pues a no estar muerto, él rebuznara si nos oyera, o no fuera asno; pero a trueco de haberos oído rebuznar con tanta gracia, compadre, doy por bien empleado el trabajo que he tenido en buscarle, aunque le he hallado muerto». «En buena mano está, compadre - respondió el otro-, pues si bien canta el abad, no le va en zaga el monacillo». Con esto, desconsolados y roncos se volvieron a su aldea, adonde contaron a sus amigos, vecinos y conocidos cuanto les había acontecido en la busca del asno, exagerando el uno la gracia del otro en el rebuznar... (II, 25).

Sugiero entonces considerar si acaso este pasaje no nos presenta una reflexión burlesca - pero reflexión al fin - acerca del crucial planteo sobre la finalidad del arte. Puesto que los regidores parecen descubrir que un provecho indudable de lo que han experimentado se halla en el deleite. ¿Es esta una idea de brutos que simplemente no saben elegir o hay una cierta verdad profunda que involucra la libertad del receptor?

$\mathrm{Si}$ aceptamos que el relato (que, no lo olvidemos, es contado por un defensor de los regidores) termina respaldando la idea de la utilidad en sí del disfrute estético, podremos ver que es esta idea la que se expande o resuena en el mote del único estandarte guerrero que el narrador registra y los personajes comentan ${ }^{24}$, aquel que dice «No rebuznaron en balde / el uno y el otro alcalde ${ }^{25}$. Creo que al considerar el mote bajo esta luz - en la oposición inutilidad o provecho - termina de cobrar sentido lo que de otra forma no vemos más que como un nuevo elemento ridículo del episodio.

Desde esta perspectiva, el estandarte nos podría estar indicando un modo de lectura de lo sucedido, porque nos permite proponer que aquel grito de guerra condensa lo que se exalta en la historia total de los rebuznadores, es decir que, por más absurdo que parezca, la curiosa aventura en el monte valió la pena y resulta reivindicada por los del pueblo, así como por sus protagonistas (recordemos el «doy por bien empleado el trabajo que he tenido en buscarle» que decía el dueño del burro). Por lo demás, la afirmación de la empresa guerrera, nos hace volcar la atención al hecho de que el enfrenta-

24. De entre los muchos que enarbolaban los combatientes del pueblo en el capítulo 27.

25. No queda claro si se trata de un refrán anterior a este uso de Cervantes, Bizzarri no lo registra como tal y curiosamente el refrán registrado por Correas es «Rebuznaron en balde el uno y el otro alcalde». Aunque el Vocabulario de Correas es posterior a Cervantes (1627), bien podría ser que se tratara de un refrán conocido que nuestro autor modifica adrede agregándole la negación y dejando los "alcaldes" que mantenían la rima. 
miento está asentado, nuevamente, en un conflicto interpretativo o de juicio: ¿rebuznaron o no en balde (el uno y el otro alcalde)? ${ }^{26}$.

Como narra en el final de su relato el portador de armas, más allá de que los regidores involucrados hubieran terminado conformes con su experiencia y que ellos mismos se encargaran de difundirla con gusto entre sus amigos y vecinos, desde los otros pueblos no juzgaron lo acontecido con la misma benevolencia. Como es común e inevitable, lo que se hace público queda a merced de opiniones; lo que se publica se abre a juicios y a pareceres distintos. Eso fue lo que pasó con la difusión de la historia de los maravillosos rebuznos, sobre la que surgen voces que, en lugar de admirarse como los regidores, no tardaron en burlarse de ellos, como cuenta el de las lanzas:

... todo lo cual se supo y se estendió por los lugares circunvecinos; y el diablo, que no duerme, como es amigo de sembrar y derramar rencillas y discordia por doquiera, levantando caramillos en el viento y grandes quimeras de nonada, ordenó e hizo que las gentes de los otros pueblos, en viendo a alguno de nuestra aldea, rebuznase, como dándoles en rostro con el rebuzno de nuestros regidores (II, 25).

El final es notable porque al hablar del rumor que se extiende sembrado por el diablo y utilizar la frase proverbial «levantar caramillos en el viento», no podemos obviar la posible alusión a otra parte de la fábula del rey Midas relacionada con la anteriormente comentada, aquella que refiere al secreto sobre las orejas de asno que Apolo le había dado como castigo por su mal juicio.

Hugo Bizzarri registra la frase «levantar caramillos» en su Diccionario de paremias cervantinas y reproduce la discusión que los anotadores han tenido al respecto, para terminar sosteniendo que la expresión significa «levantar falsos rumores»; aunque también recoge el sentido dado por Alonso Hernández en su Léxico del marginalismo y que parece mejor en este preciso contexto: «Decir mal de alguno». En lo que atañe a la alusión mencionada, lo especialmente curioso es el uso del verbo 'sembrar' y el término 'caramillos' que en sentido literal refiere a ciertas cañas y también al instrumento musical que se hace con ellas (Tesoro, s. v. 'caramillo' y también DRAE, s. v. 'caramillo', con una segunda acepción que significa «chisme, enredo, embuste»).

Según la fábula, el barbero real era el único que había visto las monstruosas orejas del rey Midas y debía guardar silencio o le costaría la vida, pero el secreto le pesaba tanto que no pudo contenerse, por eso un día fue al campo, cavó un pozo y dijo en el hueco «el rey Midas tiene orejas de asno», volvió a taparlo y se alejó, tan aliviado como confiado de que nadie se enteraría. Sin embargo, del lugar donde «sembró» el secreto nacieron unas cañas que movi-

26. Cabe recordar aquí los inspiradores análisis de Forcione (1970) acerca del alegato en favor de la libertad creadora - y también lectora - en las discusiones metaliterarias de las obras cervantinas. De especial interés para nuestro asunto son sus capítulos sobre el diálogo entre don Quijote y el Canónigo (1970: 91-130) así como las reflexiones en torno al narrador y su audiencia (1970: 131-166). 
das por el viento vocearon la verdad sobre las orejas del rey; luego de las cañas se hicieron instrumentos, caramillos, que al ser tocados repetían lo mismo: «El rey Midas tiene orejas de asno». La leyenda era muy conocida en tiempos de Cervantes y él mismo hace una alusión muy clara en el Persiles $^{27}$.

Como nueva muestra de lo presente de la fábula en el contexto cultural cervantino, podemos ver el emblema de la colección de Hernando de Soto Emblemas moralizadas (1599: f. 56) que la utiliza para transmitir el concepto de que los secretos no pueden guardarse indefinidamente.

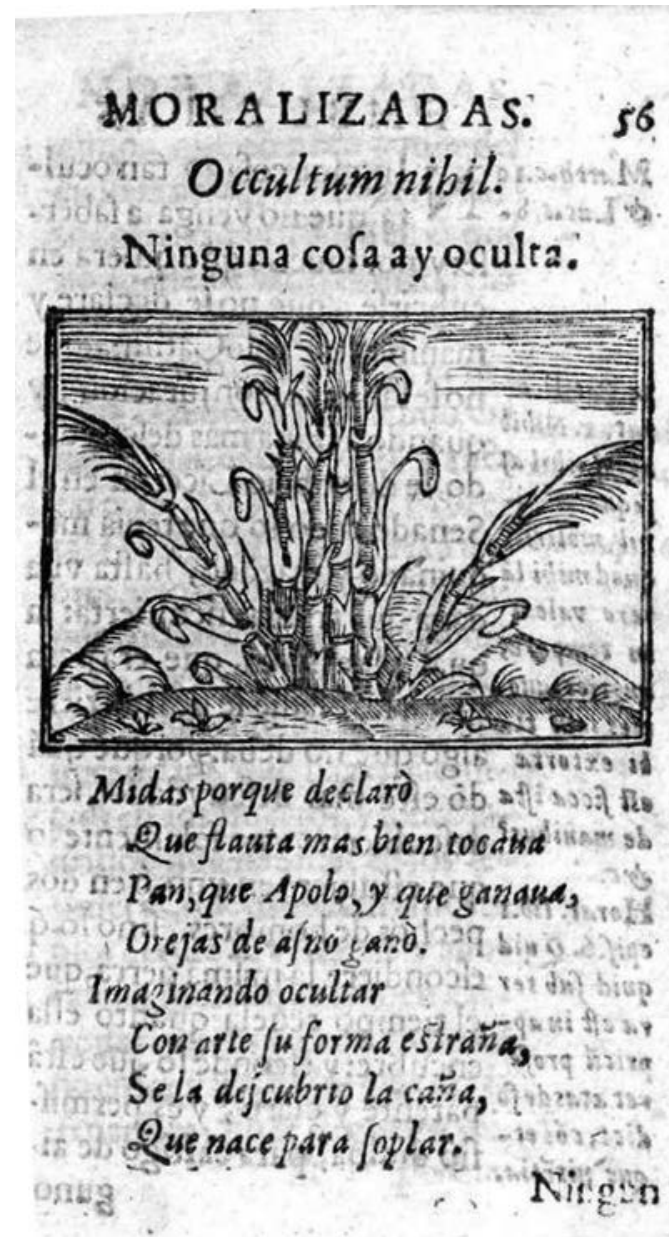

Figura 5. Soto, Emblemas moralizadas, 56.

27. En el Persiles quien la recuerda es el malediciente Clodio cuando dice: «... si quieren que no hable o escriba, córtenme la lengua y las manos, y aun entonces pondré la boca en las entrañas de la tierra, y daré voces como pudiere, y tendré esperanza que de allí salgan las cañas del rey Midas» (I, 14). Se cuenta en las Metamorfosis XI, vv. 483-485. 
En definitiva, hemos intentado señalar ciertas líneas sutiles que en este episodio tejen redes de sentido acerca de la creación y la apreciación artística o el juicio, pero también como veremos a continuación, una reflexión sobre la condición humana.

Para entrar en este último tema, y continuar con Soto, podemos considerar cómo en un emblema posterior, el mismo autor vuelve a utilizar las orejas de Midas como ejemplo vitando. Este emblema, recordando el castigo de Apolo que le hizo crecer a Midas sus vergonzantes orejas, tiene como finalidad conceptual advertir sobre la ignorancia que hace al hombre caer en la animalidad.

\section{MORALIZADAS. $\quad 86$ \\ Ignorantis digna laùrus. \\ Ellaurel del ignorante.}

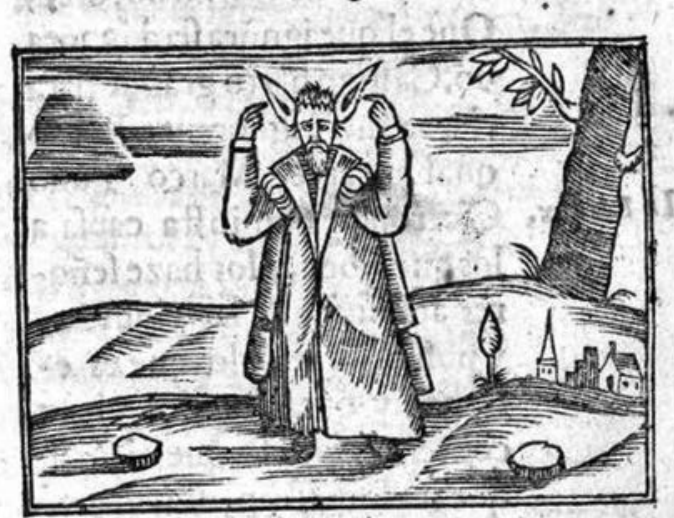

Es la ignorancia de forma,

Si a cafo nofe limita,

Que el fer de böbre, al böbrequitia

Como en bestia le transforma.

Forma defta femejante

Se dio a Midas por afronta:

En la qual / e reprejenta

Ellaurel del gignoranie.

FIGURA 6. Soto, Emblemas moralizadas, 86. 
Cabe tener siempre presente la relación directa entre el asno y las tan relevantes reflexiones sobre la locura en el Renacimiento ${ }^{28}$. En primer lugar y dentro de nuestro enfoque, no olvidemos que la locura se equiparaba a necedad: el loco podía ser el que entendía mal, el que no sabía, es decir, el necio o stulto ${ }^{29}$. En segundo lugar, recordemos que originalmente las caperuzas de los bufones o locos de corte representaban las orejas del asno, como forma paradigmática de la animalidad y la falta de juicio. Basta recordar, para notar la importancia central de los asnos en la imaginería de la locura, el testimonio de la Stultifera navis de Brant (1494), donde los asnos y los hombres con caperuzas, que remedan las orejas de asnos, son una presencia constante.

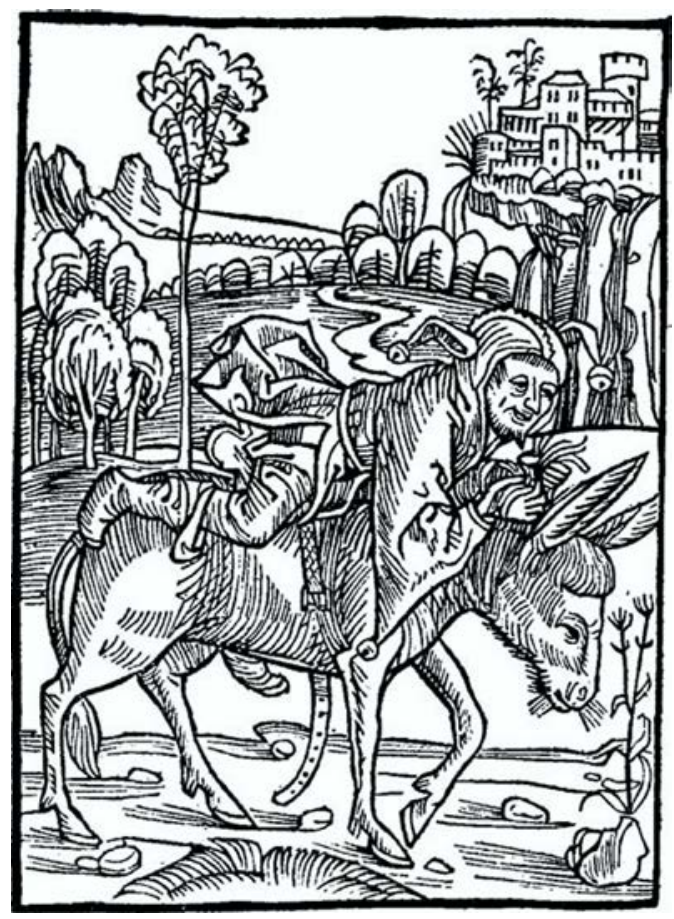

FiguRA 7. Brant, Stultifera navis, 12, Del necio ignorante.

Se hace evidente en tales relaciones que el asno figura como animal referenciador que advierte sobre el peligro de la transformación: a causa de la locura o la necedad el hombre puede dejar de ser hombre para transformarse

28. El reciente libro de Belén Atienza (2009) acerca las perspectivas del transitado tema de la locura renacentista a los testimonios del Siglo de Oro y establece correlatos de especial interés con la iconografía de la locura contemporánea. Un meditado y completo compendio del tema puede consultarse en Ciordia (2007).

29. Sabido es que en los salterios iluminados el necio que niega la existencia de Dios solía ser representado como un bufón (Dixi insipiens in corde suo: «Non est Deus», salmo 14 y salmo 52). 
en bestia; más específicamente, en asno. Así lo ilustra el famoso grabado del capítulo 37 de la obra de Brant, en la que la rueda de la fortuna gira (guiada por la mano de Dios), haciendo subir o bajar a hombres-asnos, que se van transformando a mitad de camino entre la humanidad o la bestialidad según las vueltas de la fortuna ${ }^{30}$.

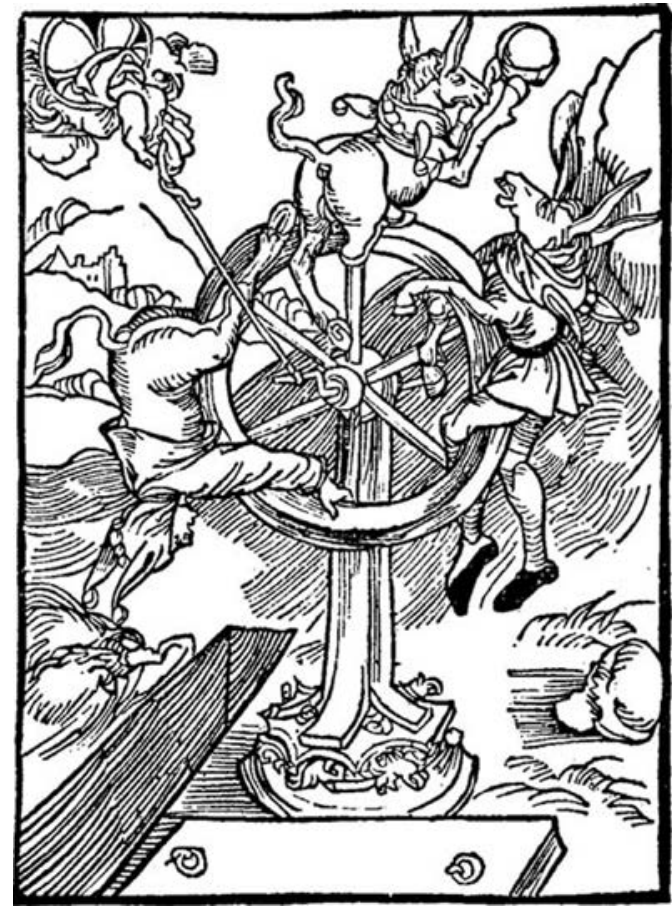

Figura 8. Brant, Stultifera navis, 37, El azar.

Por lo demás, hay que recordar que la unificación de todos los hombres alcanzados por la condición común de la locura, difundida por Erasmo en su Elogio, se identifica con la idea de que todos los hombres tienen algo de $\operatorname{asnos}^{31}$. Idea con plena vigencia en la España del Siglo de Oro como nos lo muestra la frase del narrador de la Primera parte del Guzmán de Alfarache cuando afirma: «Larga es la cofradía de los asnos, pues han querido admitir a los hombres en ella» (I, ii, 2) ${ }^{32}$; de manera risueña y contundente el concepto aparece también en el pórtico del Quijote como sentencia inapelable en boca de Rocinante en su diálogo con Babieca: «Asno se es de la cuna a la

30. El mismo grabado se repite en el capítulo 56 que trata sobre el final o el abandono del poder.

31. Las referencias en el Elogio a los asnos y en especial a las orejas de asno como índice de la estulticia son persistentes.

32. La misma idea se refiere repetidas veces en el Guzmán de Alfarache (Joly 1983; Guillemont y Requejo Carrió 2007). 
mortaja $\rangle^{33}$. La reflexión profunda que está detrás de estos comentarios risueños sería equivalente a la locura positiva de Erasmo; es decir, el reconocimiento de la propia bestialidad aparece como el primer paso para el autoconocimiento y la aceptación de las paradojas constitutivas del hombre ${ }^{34}$.

Guillemont y Requejo ya señalaron de qué manera en los textos cervantinos la asinidad acentúa la unión de contrarios como algo positivo que lleva al autoconocimiento; en la ambigüedad burlesca de la figura del asno se promueve la capacidad del individuo para librarse del vicio reconociendo sus propias contradicciones y limitaciones: «Cervantes, al asociar desde las piezas liminares la materia asinina con la locura, delinea un espacio ambiguo, en el que la parodia de la novela de caballerías que caracteriza su proyecto novelesco se enriquece con nuevos sentidos» (Guillemont y Requejo 2007: 71).

\section{CON O SIN COLA: EL ESPEJO DEL MONO}

La llegada de Maese Pedro con el mono adivino provoca que se cambie el foco y el juicio se traslade de los imitadores de asnos, a los espectáculos que el proteiforme personaje produce: el ventero alaba al titiritero y juzga como insuperables su retablo y las habilidades del mono. Si bien todos los de la venta son invitados a participar de la función gratuita, don Quijote pasa a convertirse en espectador privilegiado y en el juez más concienzudo. Pronto las hazañas del mono halagan su orgullo porque inmediatamente es reconocido y saludado como caballero andante famoso; el narrador nos indica que queda admirado por semejante espectáculo más allá de lo que creía posible «¿qué persuasión fuera bastante para persuadirme que hay monos en el mundo que adivinen, como lo he visto ahora por mis propios ojos?» (II, 25).

Luego, sus críticas a la representación en el retablo muestran a las claras su función de crítico y juez. Resulta notable que sus comentarios son sensatos y hasta adecuados a los fines de producir una representación acorde con los principios de la verosimilitud; pero su juicio (en todo sentido) se pierde cuando los amantes que huyen son perseguidos de cerca por los moros y el trujamán comenta: «Témome que los han de alcanzar y los han de volver atados a la cola de su mismo caballo, que sería un horrendo espetáculo». Y don Quijote obnubilado se levanta y responde «-No consentiré yo que en mis días y en mi presencia se le haga superchería a tan famoso caballero y a tan atrevido enamorado como don Gaiferos» (II, 26) ${ }^{35}$.

33. «Diálogo entre Babieca y Rocinante» (Quijote, I, Versos preliminares); véase el clásico estudio de Adrienne Laskier Martin (1990).

34. Margolin (1965: 33-54) analizaba con claridad la moderna mirada humanista que plantea Erasmo acerca de la locura como constitutiva del hombre y la consciencia irónica como motor del autoconocimiento.

35. A raíz de lo que se analizará a continuación en este estudio, cabe retener la referencia a la cola del caballo en este posible regreso afrentoso de los protagonistas del retablo. 
De modo que don Quijote, como suele, ha mostrado ser un juez a dos luces; por momentos fue sensato y prudente, guiado por ideales de mímesis artística, pero luego — cuando su propia imitación mimética del ideal caballeresco toma posesión de sus acciones - no hace más que actuar neciamente, perdiendo el juicio y transformándose en una farsa, como si fuera un mono que imita sin criterio.

Veamos ahora sus preocupaciones previas con el mono adivino. Don Quijote no considera al mono como parte de un engaño, no parece recordar en ningún momento las tradicionales conexiones del mono con la imitación (que lo podrían hacer sospechar que el animal había aprendido a imitar los gestos del habla humana), ni tampoco, por supuesto, lo ve como símbolo de la lujuria ni de la vanagloria, que son otras dos atribuciones tradicionales muy vigentes en su contexto cultural. Solamente parece pensar en otro sentido detrás del mono que se liga a una de las atribuciones simbólicas más antiguas que recaen sobre este animal: la conexión diabólica.

\begin{abstract}
Don Quijote no estaba muy contento con las adivinanzas del mono, por parecerle no ser a propósito que un mono adivinase, ni las de por venir ni las pasadas cosas, y, así, en tanto que maese Pedro acomodaba el retablo, se retiró don Quijote con Sancho a un rincón de la caballeriza, donde sin ser oídos de nadie le dijo:

- Mira, Sancho, yo he considerado bien la estraña habilidad deste mono, y hallo por mi cuenta que sin duda este maese Pedro su amo debe de tener hecho pacto tácito o espreso con el demonio (II, 25).
\end{abstract}

Entre las representaciones culturales que Janson recoge en su estudio sobre los monos en la tradición occidental del Medioevo al Barroco, una de las más antiguas es la que veía al mono como figura del demonio o incluso como representación del pecado (Janson cap. 1), para pasar luego a transformarse en la representación del hombre pecador, es decir, como la víctima del diablo, antes que como el diablo mismo (Janson cap. 2). Tales representaciones se encuentran con facilidad en el arte medieval, tanto en iluminaciones de manuscritos, como en figuras talladas en piedra de templos románicos ${ }^{36}$.

Es de especial interés para nuestro recorrido notar que incluso en esta conexión diabólica ancestral, la cuestión de imitación es la base o sustento conceptual. En efecto, el mono era figura del demonio porque así como Lucifer quiso imitar a Dios y fue castigado, los monos también hacen imitaciones defectuosas de los hombres y quedan en ridículo (Janson: 19-20). Incluso, en algunas historias muy difundidas, se explica que los monos habían sido personajes soberbios y temerarios que enfurecieron a la divinidad y, como castigo, fueron convertidos en simios ( $c f$. Janson: 16-18 y 94-99; García Arranz 2013: 216) ${ }^{37}$. Apreciamos, entonces, cómo la imitación, desde esta

36. Véase un compendio de imágenes completo y de fácil consulta en Walker Vadillo 2013.

37. Covarrubias en su Suplemento al Tesoro recoge la historia de Epimeteo y dice: «Epimetheus. Fue hijo de Jápeto y hermano de Prometeo. Fue ingeniosísimo y el primero que contrahizo con barro 
perspectiva, apunta directamente a la acción desmesurada de querer ser más de lo que se es.

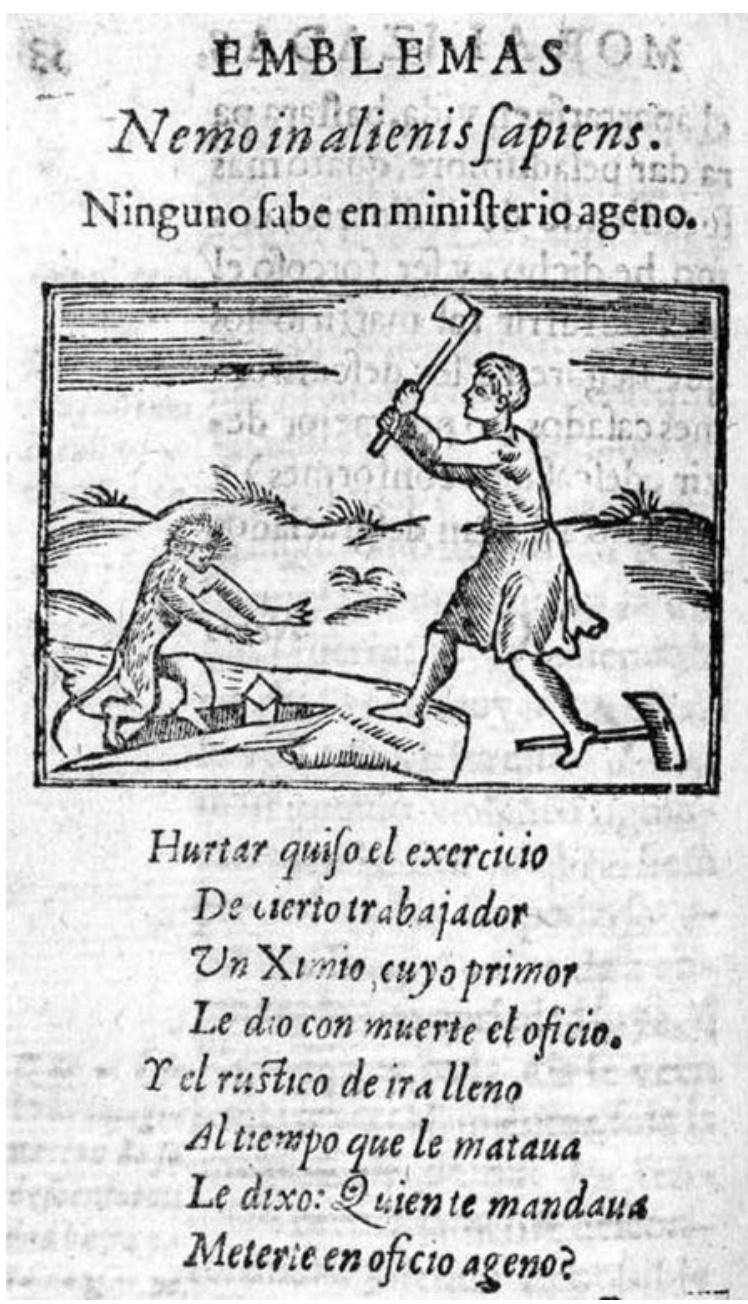

FIGURA 9. Soto, Emblemas moralizadas, 54.

la estatua del hombre y su figura. Es nombre griego epimêtheus, a verbo epimêdomai, excogito, que vale discurrir con el entendimiento como él lo hizo en la fábrica del hombre de barro, de lo cual indignado Júpiter le convirtió en simio y le desterró a las islas de los monos, dichas Pitecusas». Janson (290-291) indica que el registro más antiguo de la historia de Epimeteo se encuentra en la Genealogía de los dioses paganos de Boccaccio (libro IV, 42); Juan Pérez de Moya en su Philosofia secreta (1585) la recoge en el libro VI, capítulo II siguiendo a Boccaccio. Por otro lado, el relato legendario se plantea como una amenaza latente para justificar el temor del hombre de traspasar los límites que lo separaban de la bestialidad, división que se había hecho muy porosa en el pensamiento renacentista (Knowles: 142). 
Como ejemplo y testimonio de la vigencia de esta idea en el Siglo de Oro, tenemos un emblema de Hernando de Soto, «Nemo alienis sapiens [Ninguno sabe en ministerio ajeno]»: un campesino ajusticia a un mono que tomó sus herramientas y quiso imitarlo. En el emblema se retrata al mono como usurpador de un lugar que no le correspondía y la glosa hace una advertencia explícita en contra de la impertinencia de las pretensiones desmesuradas o los saberes vedados:

Reprende el sabio a todos los que quieren saber más de lo puede alcançar a capazidad de su entendimiento. Y dizeles, que no busquen ni escudriñen lo que es mas alto y mas fuerte que ellos: porque ninguno ha de procurar saber mas de lo que viere que comprehende su subjeto, midiéndose con el. (f. 54 r)

Para acentuar las sospechas sobre la condición maligna del mono de maese Pedro, recordemos que desde el principio se lo caracterizó como un mono de los que no tienen cola. Precisamente los primeros monos que los europeos conocieron eran de este tipo y no fue hasta la Baja Edad Media, gracias a la apertura mercantil experimentada en Europa hacia el siglo XII, que entraron en contacto con otros simios que sí tenían cola. Esto es destacable porque la falta de cola fue considerada durante la Antigüedad y gran parte de la Edad Media como una inquietante señal de la condición ambigua de estos animales. En efecto, de un precario conocimiento del mundo animal proviene la observación de la semejanza del mono con el hombre por la falta de cola, dado que se creía que tanto el hombre como el mono eran los únicos animales creados por Dios que carecían de este apéndice.

En los bestiarios medievales, deudores del Fisiólogo ${ }^{38}$, esta particularidad era especialmente señalada y llegó a convertirse en un indicio de la soberbia y caída del simio (que habría ocupado antes otro nivel en la cadena del ser). La interpretación cristiana medieval sostenía que la cola en los animales muestra que se trata de seres completos y con una finalidad determinada por Dios, puesto que tienen un principio (la cabeza) y un final (la cola). Solamente el hombre es libre de elegir su propio destino y por tal motivo es el único animal legítimamente sin cola; en el simio, en cambio, su ausencia señalaría una falla, una caída, similar a la del demonio que había sido creado como ángel pero por su soberbia perdió el cielo: en esta semejanza el simio sería tanto imagen del diablo como de un hombre caído (Janson: 18-20).

38. En el Fisiólogo en edición de Guglielmi leemos «el simio [...] asumió el papel del diablo: tuvo principio, pero carece de fin (es decir, de cola); al principio fue uno de los arcángeles, pero su fin se desconoce. Con razón, pues, el simio, que no tiene cola, carece de belleza; pues lo más vergonzoso es carecer de cola. Y lo mismo le ocurre al diablo, no tiene fin bueno» (65-66). El famoso Bestiario de Aberdeen del siglo XII retoma y amplía el comentario sobre el mono, aquí se encuentra accesible en original y traducción inglesa: $<$ https://www.abdn.ac.uk/bestiary/ms24/f12v>. Sobre las relaciones del Physiologus en simbolismo animal de la época que nos ocupa, véase García Arranz 2014. 
En definitiva, por más extraño que parezca, la falta de cola termina resultando una marca de soberbia, como una señal del que aparenta ser más de lo que es, ya sea porque se quiere «imitar» al hombre en el no tener cola o porque esa falta indica una caída (habrían sido hombres castigados por pretensiones soberbias y convertidos en monos) $)^{39}$. Tal es así que, con o sin cola, en la suma de sus variadas características simbólicas, aquello que más permaneció vigente - sostenido también por la acción imitativa - es la figura del mono o de la mona como imagen de la vanagloria o el autoengaño. Pensemos que resabios de esa idea incluso permanecen entre nosotros («Aunque la mona se vista de seda, mona queda»); e indudablemente eran muy relevantes en el Siglo de Oro, como nos lo muestra nuevamente ese gran reservorio de representaciones y cultura simbólica que es la emblemática.

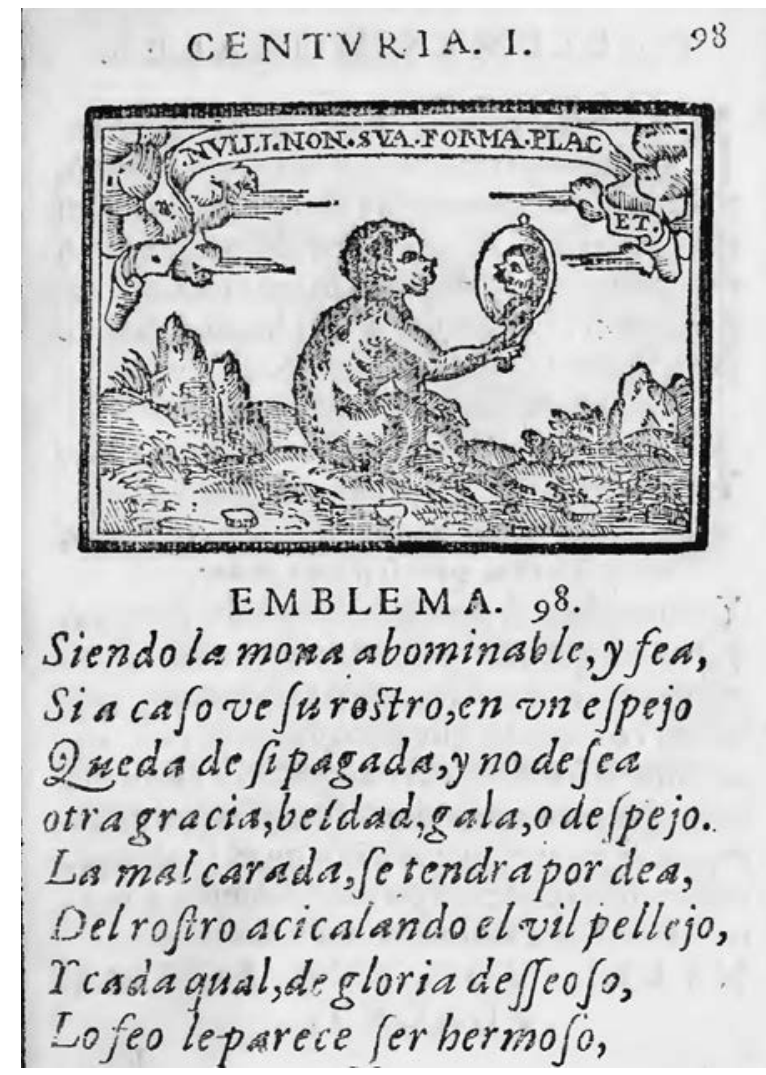

Figura 10. Covarrubias, Emblemas morales, Cent. I, emblema 98.

39. Vale la pena ahora tener presente que, como citamos antes, cuando Alfonso de Carvallo hablaba del mal poeta como una mona que copia sin criterio, se burlaba del animal porque intenta parecerse al hombre pero solamente lo logra «en la liviandad de la risa y en las nalgas» (1958: 182); es decir, en una parte trasera sin cola. 


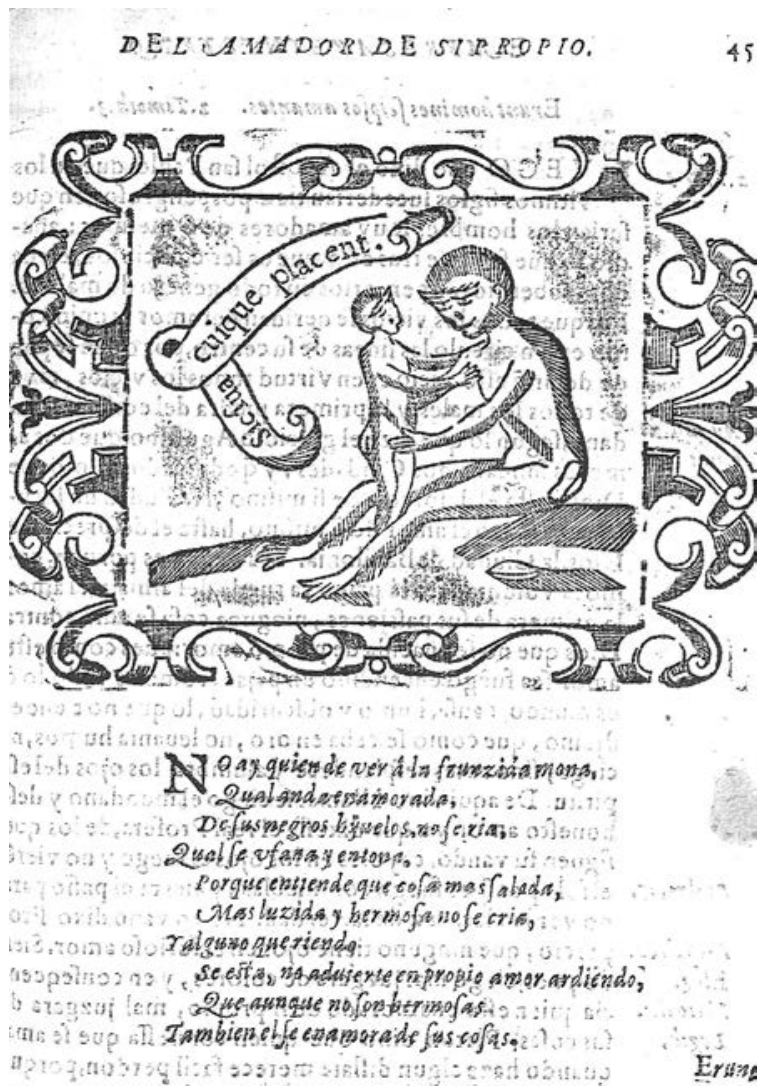

Figura 11. Villava, Empresas espirituales y morales, Segunda parte, empresa 23: del amador de sí propio.

\section{TRAS ASNOS Y MONOS SE ASOMA EL HOMBRE}

A partir del recorrido realizado podemos afirmar ahora que así como el asno es el animal más utilizado para representar en la época la animalidad consustancial al hombre o la animalización fruto de la ignorancia, el mono se ligaba a las pretensiones engañosas, cargadas de simpleza autocomplaciente o bien, lisa y llanamente, de soberbia. En definitiva, ambos animales son especialmente utilizados como modelos de conducta para el hombre: así como el mono es el símbolo del que pretende ser lo que no es, el asno muestra la condición del que no se esfuerza siquiera por ser hombre.

Igualmente no debemos dejar de lado que, como bien nos recuerdan Guillemont y Requejo, existía una mirada más benevolente sobre el asno, una asinidad positiva a través de la cual se valoraban otras características del asno en especial al considerarlo como trabajador incansable, sufridor de inclemencias y muy buen compañero del hombre; así pues, el asno era también en la 
época de Cervantes un modelo ejemplar de humildad y perseverancia. No encontramos una contracara positiva igual de persistente para el caso del mono en la época de Cervantes, más allá de la ya reseñada reivindicación renacentista como la figura del arte que imita de naturaleza ${ }^{40}$.

En tanto modelos ejemplares, ambos animales servían notablemente como espejo para reflexionar sobre la ambigüedad de la condición humana y las posibilidades que tiene el hombre de devenir ángel o bestia según potencie su espíritu divino o su materialidad animal. Seguramente por eso en las representaciones simbólicas del asno y del mono en el Siglo de Oro, aparece con tanta frecuencia el repetido llamamiento al desengaño y al autoconocimiento. Cuestión bifronte que resulta también de vital importancia en el Quijote de 1615.

Es con esto en mente que quisiera destacar cómo la incidencia simbólica de los dos animales que hemos estado persiguiendo en estas páginas no se acaba con la salida de la venta ni con la partida de maese Pedro y su retablo. La curiosa imbricación de los dos episodios enlazados en su comienzo en la mitad del capítulo 25, también encuentra su cierre en un entrelazamiento «innecesario» en el capítulo 27 cuando se cuenta la verdad sobre maese Pedro, para luego pasar al modo en que don Quijote y Sancho se topan (después de tres días de camino que no merecen relato) con el escuadrón del pueblo del rebuzno preparado para la batalla. En los acontecimientos que allí ocurren y en el diálogo posterior entre los protagonistas, van a seguir teniendo relevancia las figuras del mono y, en especial, del asno.

El don Quijote que sale de la venta, contrito y arrepentido por los destrozos que había ocasionado su juicio insensato y su compenetración en el mundo ficcional del retablo, da nuevas muestras de su prudencia y sabiduría en su arenga en contra de la guerra. En primer lugar, recordemos que don Quijote cuestiona las razones de la ofensa que experimentan los del pueblo del rebuzno y por lo tanto lo inadecuado de la venganza que planean. Luego, el alarde como rebuznador de Sancho va en la misma línea porque lo que él sostiene es que «es necedad correrse por sólo oír un rebuzno» y se vanagloria sobre cómo solía rebuznar de muchacho con «gracia y propiedad», actividad por la que era envidiado ${ }^{41}$. Sancho muestra su «arte», pero su acción resulta mal interpretada («Pero uno de los que estaban junto a él, creyendo que hacía burla dellos, alzó un varapalo...») y esto da pie al comienzo del conflicto.

40. Merece recordarse también la peculiar injusticia que la tradición occidental ha cometido con la figura del mono, precisamente por ser más parecido a los hombres que los otros animales. Así, en las fábulas clásicas el mono nunca ha tenido una clara definición en relación con el resto de los animales, generalmente porque como su inteligencia era tan alta, en lugar de compararlo con los demás animales, se lo comparaba con los humanos y consiguientemente se lo hacía parecer estúpido frente a los hombres. En las fábulas medievales pasaba lo mismo; si los personajes eran todos animales, no se le otorgaba al mono el lugar de excelencia que tenía, por ejemplo, la astucia del zorro quien siempre superaba al mono; si en cambio se lo incluía en una fábula de ambiente humano, el mono quedaba representado no como un animal inteligente, sino como un simple necio (Janson: 39-40).

41. Muy atendible también es la lectura de Ly sobre la «agudeza» de Sancho (2016), una mirada sobre reversibilidad del personaje que no invalida lo que aquí observamos. 
Así pues, si don Quijote se había mostrado especialmente sensato y justo razonador con su discurso, Sancho cae en la mayor necedad imaginable al interrumpirlo con su propio alarde del arte o ciencia de rebuznar. Como resultado de todo esto, Sancho recibe golpes que van de una punta a otra del espinazo $^{42}$, mientras don Quijote intenta defenderlo con su lanza, pero lo superan en número y las armas modernas lo hacen optar por la retirada.

Más adelante, ante las reprensiones del amo por su rebuzno inoportuno, Sancho responde con un amargo desengaño de su labor de escudero, por el que ningún bien consigue, y despliega varias exigencias sobre su justo salario. Los reclamos que le hace Sancho a don Quijote por haberlo abandonado plantean las fallas que ve en él como caballero andante. En cierta forma, Sancho cuestiona la acción mimética de don Quijote como seguidor de modelos caballerescos. Incluso se produce un claro desengaño, desde la óptica de Sancho, pues si don Quijote no había dudado en defender a Gaiferos y Melisendra de las huestes de los moros (por más títeres que fueran), no había actuado con la misma lealtad hacia él frente a los del pueblo del rebuzno que lo atacaban. Por eso Sancho reconoce con amargura sus errores de juicio previo: «... cada día voy descubriendo tierra de lo poco que puedo esperar de la compañía de que con vuestra merced tengo...» (II, 28). Cuando don Quijote le concede la libertad para quejarse y para calcular la justa retribución que se merece, Sancho, cegado por la ambición, termina encumbrándose en una engañosa y desmesurada soberbia, pues incluso llega a reclamarle a don Quijote la inaudita cantidad de veinte años de servicios.

Don Quijote, que había sido relativamente paciente con él hasta ese momento, se ofende con estos reclamos desproporcionados y lo toma como una traición, pero especialmente - para el interés de nuestro recorrido - lo trata de bestia: « $\mathrm{O}$ Oh pan mal conocido, oh promesas mal colocadas, oh hombre que tiene más de bestia que de persona!» (II, 28). Y, desde ya, que no se trata de cualquier bestia: «Asno eres, y asno has de ser, y en asno has de parar cuando se te acabe el curso de la vida, que para mí tengo que antes llegará ella a su último término que tú caigas y des en la cuenta de que eres bestia» (II, 28).

Notemos que lo acusa entonces de dos errores: la soberbia que lo lleva al desagradecimiento, por un lado; pero también la necedad que lo lleva al desconocimiento de sí, al no darse cuenta de que es necio ${ }^{43}$. La respuesta de Sancho es un arrepentimiento fundado en el reconocimiento de la bestialidad intrínseca del ser humano (signada curiosamente en la cola que marca la distinción más evidente):

42. Una mención corporal que nos hace pensar en la cola, el apéndice natural que une a los animales de una punta a la otra, como también lo recuerda Diego Carriazo o Lope Asturiano en $L a$ ilustre fregona cuando reclama la cola del asno apostado.

43. Sancho cayó en los dos errores paradigmáticos de los animales que estudiamos: soberbia como los monos y necedad como los asnos. 
Miraba Sancho a don Quijote de hito en hito, en tanto que los tales vituperios le decía, y compungióse de manera que le vinieron las lágrimas a los ojos y con voz dolorida y enferma le dijo:

- Señor mío, yo confieso que para ser del todo asno no me falta más de la cola: si vuestra merced quiere ponérmela, yo la daré por bien puesta, y le serviré como jumento todos los días que me quedan de mi vida. Vuestra merced me perdone y se duela de mi mocedad, y advierta que sé poco, y que si hablo mucho, más procede de enfermedad que de malicia; mas quien yerra y se enmienda, a Dios se encomienda.

Podemos decir que la respuesta de Sancho lo redime porque indica el camino del autoconocimiento y de la asinidad positiva (la que se basa en la humildad, la paciencia y la perseverancia). Y no cabe duda de que estas palabras lo redimen a los ojos de don Quijote, quien le responde: «Ahora bien, yo te perdono, con que te enmiendes y con que no te muestres de aquí adelante tan amigo de tu interés, sino que procures ensanchar el corazón y te alientes y animes a esperar el cumplimiento de mis promesas, que, aunque se tarda, no se imposibilita» (II, 28).

En definitiva, como hemos podido advertir, con monos y asnos, creación artística, imitación y disfrute estético, el texto trata la condición misma de qué es ser humano. Apaleado de una punta a la otra del espinazo, reprendido por su soberbia y reclamando su cola en el momento en que más muestra ser hombre, Sancho sirvió como ejemplo paradigmático en este final.

En efecto, hemos visto el recorrido de Sancho desde la imitación torpe y sin sentido, cuando quiere también él mostrar su pericia en el rebuzno, pasando luego a la soberbia de encumbrarse por encima de sus límites o capacidades - dos rasgos propios de la representación cultural del mono-; para llegar en el final de toda esta secuencia a la humildad del autoconocimiento cuando acepta la animalidad constitutiva del ser hombre y se somete nuevamente (para su mal) a los designios de don Quijote.

Preciso es notar que don Quijote va más lento que Sancho en el proceso de autoconocimiento y no sigue en estos episodios los ejemplos animales como su escudero; pero toda esta Segunda Parte es un camino hacia el desengaño - otro nombre del autoconocimiento en Cervantes - y don Quijote va dando pequeñas muestras de que sus pasos se encaminan también en esa dirección. Como sabemos, al final de la aventura del barco encantado, en el próximo capítulo, alcanza un hito destacado en esta carrera, cuando dice «todo este mundo es máquinas y trazas, contrarias unas a otras. Yo no puedo más» (II, 29). Y el narrador marca su alejamiento del río Ebro diciendo: «Volvieron a sus bestias, y a ser bestias, don Quijote y Sancho, y este fin tuvo la aventura del encantado barco» (II, 29).

Inmediatamente el encuentro con los duques lo hacen retroceder varios casilleros. O quizás no; pero esa ya es otra historia y otros animales los acompañan en su recorrido. 


\section{PARA CONCLUIR}

A dos luces, es decir, sin una pretensión de sentidos unívocos, el rastreo de manifestaciones simbólicas y representaciones culturales que descubrimos en relación con temas centrales de estos capítulos del Quijote, nos confirman la riqueza de la creativa ambigüedad cervantina. En efecto, comprobamos que los significados que se agolparon en nuestro recorrido no son determinantes ni excluyentes; sino que más bien sobrevuelan como sugerencias, ensanchando el amplio espectro de problemas e interrogantes que la obra pone en juego. Tampoco encontramos un uso unidireccional de las representaciones simbólicas; por el contrario, parecen aprovecharse las multiplicidades intrínsecas del símbolo, aun en un contexto cultural que preconizaba la univocidad y la ortodoxia.

En este sentido, el camino hacia el conocimiento y el desengaño parece jugarse en la obra cervantina en base a la aceptación de la complejidad: la postulación de una vía de autoconocimiento que, sin negar las flaquezas y las fallas, propone un modelo de hombre que puede abrazar las paradojas y fortalecerse en la unión de sus incongruencias. Como el mono feliz en su imitación imperfecta o el asno que elige lo rústico porque es aquello en lo que se deleita.

Quizás resuena en lo que digo una de las admirables afirmaciones de la Locura en el Elogio de Erasmo:

[Los filósofos protestan:] «Es una desgracia estar dominados por la locura: errar, engañarse, ignorar». Antes bien, esto es ser humano. [...] Y no hay desgracia en ser conforme a la propia especie, a no ser que quizás alguien estime deplorable al humano porque no puede volar como las aves, ni avanzar en cuatro patas como el resto del género animal [...] Ergo, si un caballo imperito en gramática no es desgraciado, tampoco un humano loco es infeliz, en razón de que estas cosas son coherentes con su naturaleza (Erasmo [cap. 32]: 57).

\section{BIBLIOGRAFÍA CITADA}

Atienza, Belén (2009). El loco en el espejo: Locura y melancolía en la España de Lope de Vega. Ámsterdam: Rodopi.

Bernat Vistarini, Antonio, John Cull y Edward J. Vodolokys (1999). Enciclopedia de emblemas españoles ilustrados. Barcelona: Akal.

Bizzarri, Hugo O. (2015). Diccionario de paremias cervantinas. Alcalá de Henares: Universidad.

Brant, Sebastián (1998 [Basilea, 1494]). La nave de los necios, ed. y trad. A. Regales. Madrid: Akal.

Carballo, Luis Alfonso de (1958). Cisne de Apolo, ed. A. Porqueras Mayo. Madrid: Aldus, 2 vols. 
Cervantes Saavedra, Miguel de (1998). Don Quijote de la Mancha, ed. Francisco Rico. Barcelona: Crítica. Accesible en: <http://cvc.cervantes.es/literatura/clasicos/quijote>.

Ciordia, Martín (2007). «Introducción», a su edición y traducción de Erasmo de Rotterdam, Elogio de la Locura. Buenos Aires: Colihue Clásica, pp. I-CV.

Collins, Marsha (2015). «Maese Pedro y su espectáculo comunicativo», eHumanista/Cervantes. 4 , pp. 82-98.

Correas, Gonzalo de (2000 [Madrid 1627]). Vocabulario de refranes y frases proverbiales, ed. Louis Combet revisada por Robert James y Maïté Mir-Andreu. Madrid: Castalia.

Covarrubias Horozco, Sebastián (1610). Emblemas morales. Madrid: Luis Sánchez.

Covarrubias Horozco, Sebastián (2006 [Madrid 1611]). Tesoro de la lengua castellana o española, edición integral e ilustrada de Ignacio Arellano y Rafael Zafra. DVD, Colección Studiolum.

Curtius, Ernst Robert (1955). Literatura europea y Edad Media latina. México: Fondo de Cultura Económica.

D’Onofrio, Julia (2016). «De Micomicona a la jimia de bronce. Los ejemplos de una mona para construir un personaje», Boletín de la Biblioteca Menéndez Pelayo. XCII, pp. 93113.

D’Onofrio, Julia (2018). Cervantes frente a la cultura simbólica de su época. El testimonio de las Novelas ejemplares. Buenos Aires: Eudeba.

Erasmo de Rotterdam (2007). Elogio de la Locura, ed. y trad. M. Ciordia. Buenos Aires: Colihue Clásica.

Forcione, Alban (1970). Cervantes, Aristotle and the «Persiles». Princeton: Princeton University Press.

García Arranz, José Julio (2010). Symbola et emblemata avium. Las aves en los libros de emblemas y empresas de los siglos XVI y XVII. A Coruña: SIELAE (Seminario Interdisciplinar para el Estudio de la Literatura Áurea Española) y Sociedad de Cultura Valle Inclán.

García Arranz, José Julio (2013). «El mono frugívoro y la Epifanía: en torno a la iconografía del tríptico de la Adoración de los Reyes Magos, atribuido a Adrian Isenbrandt, en el Museo del monasterio de Nuestra Señora de Guadalupe (Cáceres)», en Miguel Angel Zalama y María del Pilar Mogollón Cano-Cortés (eds.), Alma Ars. Estudios de arte e historia en homenaje al Dr. Salvador Andrés Ordax. Valladolid: Ediciones Universidad, pp. 211-219.

García Arranz, José Julio (2014). «El Physiologus como fuente gráfico-textual de la emblemática animalística de la Edad Moderna», Janus. 3, pp. 73-114.

Gaylord, Mary (1998). «Pulling Strings with Master Peter's Puppets: Fiction and History in Don Quixote», Cervantes: Bulletin of the Cervantes Society of America. 18 (2), pp. 117-47.

Guillemont, Michèle y Marie-Blanche Requejo Carrió (2007). «De asnos y rebuznos. Ambigüedad y modernidad de un diálogo», Criticón. 101, pp. 57-87.

Guglielmi, Nilda (ed.) y Manuel Ayerra Redín (trad.) (1971). El Fisiólogo, bestiario medieval. Buenos Aires: Eudeba.

Haley, George (1984 [1965]). «El narrador en Don Quijote: el retablo de Maese Pedro», en G. Haley (ed.), El Quijote de Cervantes. Madrid: Taurus, pp. 269-287.

Horozco y Covarrubias, Juan (1589). Emblemas morales. Segovia: Juan de la Cuesta.

Janson, H. W. (1952). Apes and Ape Lore in the Middle Ages and the Renaissance. Londres: Warburg Institute, University of London.

Joly, Monique (1983). «Onofagia y antropofagia: significación de un episodio del Guzmán», en José L. Alonso Hernández (ed.), Literatura y folklore: problemas de intertextualidad. Salamanca: Ediciones Universidad, pp. 273-287. 
Joly, Monique (1986). «Rebuzne el pícaro. Comentario sobre el uso cervantino de una fábula de Esopo», en A. David Kossoff, Ruth H. Kossoff, Geoffrey Ribbans y José Amor y Vázquez (eds.), Actas del VIII Congreso de la Asociación Internacional de Hispanistas. Madrid: Ediciones Itsmo. Vol. 2, pp. 53-60.

Knowles, James (2004). "'Can ye not tell a man from a marmoset?: Apes and Others on the Early Modern Stage», en Erica Fudge (ed.), Renaissance Beasts: of Animals, Humans, and Other Wonderful Creatures. Illinois: University of Illinois Press, pp. 138163.

Laskier Martin, Adrienne (1990). «Un modelo para el humor poético cervantino: los sonetos burlescos del Quijote», en Actas del I Coloquio de la Asociación de Cervantistas. Barcelona: Anthropos, pp. 349-356.

Ly, Nadine (2016). «La agudeza de Sancho: del rebuzno a la cuestión de la imitación creadora», Criticón. 127, pp. 105-128.

Mañas Núñez, Manuel (2009). «Introducción»a su edición de Erasmo de Rotterdam, El ciceroniano (o sobre el mejor estilo). Madrid: Akal, pp. 11-61.

Margolin, Jean-Claude (1965). «La conscience ironique de soi ou L'Eloge de la Folie», en Érasme par lui-même. París: Éditions du Seuil, pp. 33-54.

Parodi, Alicia (2006). «La filología del rebuzno en el Quijote de 1615: desde el capítulo XVI hasta el XXVIII y XXIX», en Roberto Bein et al. (eds.), Homenaje a Ana María Barrenechea. Buenos Aires: Facultad de Filosofía y Letras-Universidad de Buenos Aires-Eudeba, pp. 393-402.

Parodi, Alicia (2017). Seminario sobre el Quijote. Buenos Aires: Eudeba.

Percas de Ponseti (1975). «El retablo de maese Pedro. El creador a imagen del diablo y a imagen de Dios», en Cervantes y su concepto del arte. Madrid: Gredos. Tomo II, pp. 584-603.

Riley, Edward C. (1954). «Don Quixote and the Imitation of Models», Bulletin of Hispanic Studies. XXXI (1), pp. 3-16. https://doi.org/10.3828/bhs.31.1.3.

Ripa, Cesare (1987 [Roma 1593]). Iconología, ed. Juan Barja, trad. Juan y Yago Barja, Rosa M. Mariño y Fernando García Manero. Madrid: Akal.

Rodríguez de la Flor, Fernando (1999). La península metafísica. Arte, literatura y pensamiento en la España de la Contrarreforma. Madrid: Editorial Biblioteca Nueva.

Rodríguez, Alberto (2004). «Del episodio del rebuzno al gobierno de Sancho: la evolución simbólica de la imagen del burro», en A. Villar Lecumberri (ed.), Peregrinamente peregrinos. Actas del V Congreso Internacional de la Asociación de Cervantistas. Lisboa: Fundaçao Calouste Gulbenkian, pp. 1675-1686.

Soto, Hernando de (1599). Emblemas moralizadas. Madrid: Herederos de Juan Íñiguez Lequerica.

Villava, Juan Francisco de (1613). Empresas espirituales y morales. Baeza: Fernando Díaz de Montoya.

Walker Vadillo, Mónica Ann (2013). «Los simios», Revista Digital de Iconografía Medieval. V (9), pp. 63-77. Accesible en: <https://www.ucm.es/bdiconografiamedieval/numero-9>.

Recibido: 11 de diciembre de 2017

Aceptado: 29 de mayo de 2018 